\title{
Anti-aging Effect of Mixed Extract from Medicinal Herbs
}

Soyoun Lee ${ }^{1}$, Hongyan $\mathrm{An}^{1}$, Woosoo $\mathrm{Kim}^{1}$, Xinxin Lu ${ }^{3}$, Hyanghwa Jeon ${ }^{2}$, Han Woong Park ${ }^{1}$, Jeongcheol Ha ${ }^{3}$, Jinhun $\mathrm{Cho}^{3^{*}}$

${ }^{1}$ Skin Science Research Center, New Life Cosmetics R\&D Center, New Life Group Corporation, Seoul, Korea

${ }^{2}$ New Life Cosmetics R\&D Center, New Life Group Corporation, Seoul, Korea

${ }^{3}$ New Life Cosmetics R\&D Center Co., Ltd, Shanghai, China

\author{
*Corresponding author: Jinhun Cho, New \\ Life Cosmetics R\&D Center Co., Ltd, 3A \\ B/D, 333, Guiping Road, Xuhui District, \\ Shanghai, China \\ Tel.: +86216445 7795 \\ Email: chojh@newlifegroup.com.cn
}

Received October 20, 2021

Revised November 12, 2021

Accepted November 29, 2021

Published December 30, 2021

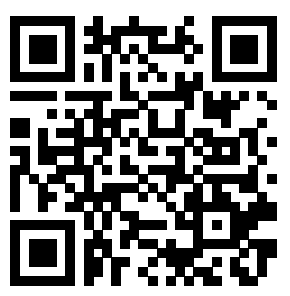

\begin{abstract}
Purpose: This study was conducted to confirm the applicability of a mixed herbal extract (MHE) as an anti-aging cosmetic ingredient by investigating its skin anti-aging activities in vitro and in vivo. Methods: In this study, we prepared MHE using an ultrasonic extraction containing Forsythiae fructus, Tribuli fructus, Solomon's seal, Siberian ginseng, Ponciri fructus and Ginseng. We investigated the anti-aging effect of the MHE for skin in dermal fibroblasts. The anti-aging activity was determined by the type I collagen synthesis levels. Matrix metalloproteinase-1 (MMP1) and tissue inhibitor of metalloproteinases 1 (TIMP1) mRNA levels were measured by qRT-PCR. MMP1 protein levels were evaluated by blotting analysis. Clinical tests of skin moisture, elasticity, texture, and wrinkles were performed using cosmetics containing 1\% MHE. Results: The MHE induced the upregulation of pro-collagen type I synthesis and TIMP1 mRNA expression. The MHE led to the downregulation of MMP1 mRNA levels and protein levels. Furthermore, after skin application of cosmetics containing 1\% MHE, skin hydration, elasticity, texture, and crow's feet were improved 4 weeks after the treatment. Conclusion: MHE has an anti-aging effect by promoting collagen synthesis and suppressing MMP1 gene expression in vitro, and it has a skin improvement effect in vivo. Therefore, the MHE was shown to have value as a functional cosmetic ingredient.
\end{abstract}

Keywords: Skincare, Anti-aging, Anti-wrinkle, Natural cosmetics, Herbal medicine

\section{Introduction}

The skin is an organ that comes into contact with the external environment and is vital for our survival, acting as the primary barrier against external attacks such as infectious agents and physical injury; additionally, it fulfills several important physiological roles (Slominski et al., 2004; Vollmer et al., 2018). As we age, skin function gradually deteriorates with atrophic changes due to ultraviolet (U.V.) rays, pollution, and stress and by skin aging that occurs as the number of skin cells and skin thickness decrease (Farage et al., 2013).

Skin aging can be divided into endogenous aging and exogenous aging. Endogenous skin aging occurs naturally over time regardless of external influences. The Dermal-Epidermal junction (DEJ) cohesion weakens, and with the differentiation of keratinocytes, lipid formation decreases (Makrantonaki et al., 2007). On the other hand, exogenous aging is caused by external factors such as U.V. rays, infrared rays (I.R.), smoking, fine dust, and lifestyle. Among these, photoaging is caused by U.V. rays penetrating the skin and damaging collagen and elastin in the dermis. In this process, the elastic fibers and collagen fibers of the skin are deformed, resulting in decreased elasticity and sagging. Collagen is a major component of the extracellular matrix and has an important role in determining tissue function. Among the various collagen types, type 1 collagen accounts for about 75-80\% of the total collagen (Landau, 2007; Lovell et al., 1987; Mays et al., 1988). When the skin is exposed to U.V. rays for a long time, free radicals are produced. These free radicals stimulate the expression of matrix metalloproteinase-1 (MMP1) that promotes collagen degradation and inhibits collagen 
synthesis which reduce skin elasticity and resulting in wrinkles. Therefore, to prevent and improve skin wrinkles caused by aging, it is necessary to develop an ingredient that promotes collagen production and inhibits the expression and activity of MMP1 (Wlaschek et al., 2001).

Skin aging is closely related to quality of life. Because the skin is the most visible organ, it makes us aware of the aging process (Binic et al., 2013). Various efforts are ongoing in the fields of medicine, pharmaceuticals, and cosmetics to prevent and improve skin aging. The development of anti-aging ingredients is one of the most important anti-aging strategies.

We have prepared herbal extracts using ultrasonic extraction to develop new anti-aging ingredients containing Forsythiae fructus, Tribuli fructus, Solomon's seal, Siberian ginseng, Ponciri fructus, and Ginseng.

Six herbal medicines were selected from plants with various medical and skin effects. Forsythiae fructus, the dried fruit of Forsythia suspensa (family Oleaceae), known as lianqiao in China, was first recorded in Shennong Bencao Jing, a prestigious monograph on traditional Chinese medicine (TCM) (Dong et al., 2017). It has been used as a heat-clearing and detoxifying TCM for the treatment of infectious diseases, such as acute nephritis, erysipelas, and ulcers (Wang et al., 2018). It is widely used in clinics as a single drug or compound prescription. Modern pharmacology has shown it to have a variety of bioactivities, including anti-inflammatory, antibacterial, antiviral, antioxidant, antitumor, anti-diabetic, antihyperlipidemic, antiandrogenic alopecia, anti-vomiting, anti-aging, and antiobesity activities and neuroprotective, hepato-protective, and vasorelaxant effects (Dong et al., 2017). In addition, it has been reported that Forsythiae fructus has skin whitening, antiatopic dermatitis, and anti-aging effects. According to Taiwan's nationwide prescription database, Forsythiae fructus has been included in the top 10 herbs most commonly used to treat atopic dermatitis (15.9\%), urticaria (11.49-13.4\%), and acne (22.3\%) (Dong et al., 2017). Forsythiae fructus contains saponins, flavonoids, and alkaloids and oleanolic acid which has a useful pharmacological action. Additionally, it contains arctigenin and matairesinol. As physiologically active skin ingredients, they are tyrosinase inhibitors that act on the melanin metabolism pathway induced by $\alpha$-melanocyte stimulating hormone $(\alpha-\mathrm{MSH})$ and are attracting attention as cosmetic whitening materials (Yang \& Choe, 2011). Tribuli fructus, which is the dried fruit of Tribulus terrestris $\mathrm{L}$, has been reported to have pharmacological activities of improving sexual function, preventing and treating cardiovascular disease, and improving neuroprotection and memory. It also has anti-diabetic, anti-inflammatory, and antioxidant effects (Chhatre et al., 2014). Tribuli fructus extract contains large amounts of diosgenin, tigogein, various saponins, etc. These saponins are the most important bioactive components responsible for various biological effects such as the aphrodisiac effect, antihypertensive effect and protective effect against ischemia-reperfusion injury and the anticancer, antibacterial and antifungal activities (Chhatre et al., 2014). Other ingredients include furostanol and spirostanol saponins, polysaccharides, flavonoid glycosides, alkaloids, and amides. In addition, it is effective against atopic dermatitis in rats and has anti-inflammatory effects (Chhatre et al., 2014). It has been reported that the anti-aging effect of Tribuli fructus extract increases the production of Type I pro-collagen and Elastin in HS68 cells, promotes the lipid accumulation of adipocytes, and ultimately improves skin wrinkles and elasticity (Kim et al., 2016). Siberian ginseng (Acanthopanax senticosus) is a deciduous shrub belonging to the family Oga along with ginseng and wild ginseng. Siberian ginseng has many similarities with ginseng and is used as an herbal medicine for stroke, high blood pressure, and diabetes. Siberian ginseng extract has been used in oriental medicine for a long time, and pharmacological and physiological results have been reported in various studies until recently. Siberian ginseng components that have been identified so far include eleutherosides A, B, C, D, E, I, K, L, and $\mathrm{M}$, and sesamin, chiisanoside, caffeic acid, chlorogenic acid, campesterol, vitamins, and minerals (Park et al., 2010). It contains triterpenoid saponins, lignans, coumarins, and flavonoids, among which the phenolic compounds are considered to be the most active components (Huang et al., 2011). There are many reports on the effectiveness of Siberian ginseng extract on the skin. Anti-wrinkle effect, antioxidant effect, collagen synthesis, and collagenase inhibitory activity against photoaging have been reported (Park et al., 2010). It has been reported that Siberian ginseng extract regulates the synthesis of Type IV collagen, affecting the proliferative capacity of epidermal stem cells and thickening the epidermis (Choi et al., 2016). Solomon's seal is a rhizome of Polygonatum odoratum (synonym: P.officinale) that has a tonic effect and is used to treat heart failure and diabetes in oriental medicine. Solomon's seal is anticycle and antitussive; it relieves heart tension, and is a diuretic, energizer, hypoglycemic, sedative, and tonic; it is used to 
treat lung diseases, including tuberculosis and gastrointestinal disorders (Haroon et al., 2012). In addition, it is widely used in the treatment of blood disorders; it has beneficial effects on the kidney ducts and prevents gray hair, vision problems, vertigo, and ringworm. It is a nervine tonic and is used in diabetes treatment (Haroon et al., 2012). Solomon's seal has a high phenol content and antioxidant activity. Homoisoflavanones from Solomon's seal inhibit the formation of advanced glycosylation end products. Solomon's seal has shown a strong intestinal immune system regulatory activity and the ability to induce osteoclast differentiation and lectin induced apoptosis. In the case of $P$. odoratum leaf extract, the wound healing function is reported as an example (Fathi et al., 2014). Ponciri fructus immaturus is the unripe fruit of Poncirus trifoliata Rafinesque, belonging to the Rutaceae family (Jung et al., 2016). Recently, anti-inflammatory and anti-hypersensitivity effects have been reported, and the effect of the extract of fat silt has been reported to induce the apoptosis of cancer cells (Lee et al., 2008). Ponciri fructus is known to be effective in treating atopic dermatitis. Through the skin application of Ponciri fructus extract, its effects against atopic dermatitis, such as epidermal hyperkeratosis, dermal edema, and cytokines, have been reported. In particular, significant decreases have been reported in itching, number of mast cells, IgE production, and nerve growth factor expression. Ponciri fructus extracts have shown an effective anti-inflammatory effect against atopic dermatitis and antipruritic efficacy by regulating immune mechanisms. In addition, oral administration of Ponciri fructus extract is known to be helpful for the treatment and prevention of allergic diseases (Hwang et al., 1997). Ginseng is a widely used traditional herbal medicine with multi-functional activities. Ginseng has been used for its anti-inflammatory, antioxidant, antitumor, and anti-aging activities (Choi, 2008; Kim \& Ko, 2020). Many studies have been conducted on the efficacy of ginseng on the skin (He et al., 2018). Among them, there are many reports on saponins and ginsenosides, which are representative ingredients of ginseng. Saponins are compounds found extensively in most plants and existing in various forms. Saponins can accelerate various biological activities such as hemolysis, and antibacterial, antiviral, and antioxidant functions. In addition, saponins have anti-inflammatory properties that can reduce swelling and skin inflammation. Ginsenosides increase interleukin (I.L.) $-1 \beta$, one of the inflammatory cytokines known to promote angiogenesis, and induce vascular endothelial growth factor and accumulation at skin burn sites in mice. Their effect of removing macrophages from skin wounds and promoting wound healing has also been reported (Kim et al., 2011).

The objective of this study was to elucidate the skin antiaging effect of a mixed herbal extract (MHE) in vitro and in vivo.

\section{Methods}

\section{In vitro efficacy evaluation}

\section{1) Preparation of the MHE}

Dried fruit of Forsythia Suspensa, dried fruit of Tribulus Terrestris L., Siberian ginseng (Acanthopanax Senticosus (Eleuthero) Root), Solomon's seal (Rhizome and root of Polygonatum Officinale), the fruit of the Poncirus Trifoliata Rafinesque, and ginseng (Panax) were purchased from a local market. Based on the "Yin-Yang" and "Five Elements" theory of Traditional Chinese Medicine (TCM), Forsythia suspensa, Tribulus terrestris L., and Poncirus trifoliata Rafinesque corresponding to "Yang" and Siberian ginseng, ginseng, and Solomon's seal corresponding to "Yin" were selected. The six medicinal herbs were again divided into the characteristics corresponding to the five elements (wood, fire, water, Metal or Gold, and Earth or soil). These medicinal herbs were mixed at the same ratio for the balance of each element, and Poncirus trifoliata and ginseng corresponding to Earth were combined

Table 1. Composition of mixed herbs

\begin{tabular}{|c|c|c|}
\hline NO. & Scientific name & $\%$ \\
\hline 1 & Forsythia suspensa fruit & 20 \\
\hline 2 & Tribulus terrestris fruit & 20 \\
\hline 3 & Acanthopanax senticosus (Eleuthero) root & 20 \\
\hline 4 & Polygonatum officinale Rhizome & 20 \\
\hline 5 & Panax ginseng root & 10 \\
\hline$d$ & Poncirus trifoliate fruit & 10 \\
\hline
\end{tabular}


with the other elements to match the proportions (Table 1). The six medicinal plants were extracted in $30 \%$ ethanol by ultrasonication $(20 \mathrm{kHz}, 2 \mathrm{~h})$. After concentrating with a rotary evaporator, 30\% (v/v) butylene glycol was added, and the solution was diluted to prepare an extract containing $1 \%$ solid contents.

\section{2) Cell cultures and reagents}

Human primary fibroblast cells (HDFn) were obtained from PromoCell (Normal human dermal fibroblasts juvenile foreskin, C-12300; PromoCell, Germany). Cell cultures with Dulbecco's modified Eagle's medium high glucose (DMEM high glucose, SH30243.01, Hyclone, Cytiva) containing 10\% (v/v) fetal bovine serum (FBS, SH30084.03, Hyclone) and 1\% antibioticantimycotic agents (Anti-anti, 15240-062, Gibco, USA) were cultured at $37^{\circ} \mathrm{C}$ in a $5 \% \mathrm{CO}_{2}$ incubator.

\section{3) Cell viability assay (MTT assay)}

The MTT assay measured the cell viability and determined the cytotoxicity of the MHE. Cells were seeded at $5 \times 10^{3}$ cells/ well on a 96-well plate and cultured for $24 \mathrm{~h}$ under cell culture conditions. Then, we discarded the medium, washed the cells with a solution of phosphate buffered saline (PBS, 21-040CV; Corning, USA), placed the cells in new serum-free media, treated the cells with concentrations of $0.01,0.025,0.05 .0 .10$, $0.25,0.50,0.75$, and $1.00 \%$ of the samples, and incubated the cells for 24 and $48 \mathrm{~h}$. Then, we added $100 \mu \mathrm{L}$ of MTT solution (0.5\%, 3-(4,5-dimethylthiazol-2-yl)-2,5 diphenyl-2Htetrazolium bromide) to each well and incubated the cells for another 2 hours. After removing the culture media, we added $100 \mu \mathrm{L}$ of $100 \%$ dimethyl sulfoxide (DMSO), shook the cells for 10 minutes, and measured the absorbance at $590 \mathrm{~nm}$ with a microplate reader (Epoch 2 microplate reader, BioTek, USA).

4) Measurement of pro-collagen type I generation
The concentration of pro-collagen type I in the cell culture medium was measured using a commercially available ELISA kit (Procollagen type I C-peptide EIA Kit, MK101, TaKaRa Bio, Japan) according to the manufacturer's instructions. Each sample was analyzed in three replicates.

5) Measurement of mRNA expression levels using Quantitative Real-Time polymerase chain reaction (qRT PCR)

Cells were seeded at $1 \times 10^{5}$ cells/well on 6 -well plates. HDFn cells were cultured for $24 \mathrm{~h}$; then, the cells were synchronized with DMEM high glucose without FBS for $24 \mathrm{~h}$. The medium was replaced with serum free media and treated with concentrations of $0.05,0.10,0.25,0.5$, and $0.75 \%$ of the samples for 24 and 48 hours. RNA extraction was performed with the HDFn cells using an RNA extraction kit (TaKaRa MiniBEST Universal RNA extraction kit, 9767A, Takara Bio, USA), and samples were purified following the manufacturer's protocols. The isolated RNA (1 $\mu \mathrm{g})$ was synthesized into cDNA using a T.R. reagent kit (PrimeScriptTM RT reagent Kit with gDNA Eraser, RR047A, Takara Bio, USA). Using a SYRB Green Realtime PCR Master Mix (Power SYBRTM Green PCR Mater Mix, 4367659, Applied BiosystemsTM, USA) and QuantStudioTM 3 (QuanStudioTM 3 Real-Time PCR instrument, A28132, Thermo Fisher Scientific, USA) real-time PCR machine, the gene expression levels were standardized to the housekeeping gene glyceraldehyde 3-phosphate dehydrogenase (GAPDH). Primers used in this study are presented in Table 2 . The experiments were performed in duplicate for three independent repeats. Melting curve analysis was performed for each primer set.

\section{6) Western blot analysis}

Protein lysates from fibroblast cells were extracted with a lysis buffer (EzRIPA Lysis Kit, WSE-7420; ATTO Corporation, Japan). The Bradford method was used to quantify the proteins.

Table 2. Primer sequences for the quantitative PCR

\begin{tabular}{|c|c|c|c|}
\hline Gene & & Primer sequences & Product length (bp) \\
\hline \multirow{2}{*}{ GAPDH } & Forward & ACC CAC TCC TCC ACC TTT GA & \multirow{2}{*}{205} \\
\hline & Reverse & CTG TTG CTG TAG CCA AAT TGC T & \\
\hline \multirow{2}{*}{ MMP1 } & Forward & GGG GAG ATC ATC GGG ACA AC & \multirow{2}{*}{220} \\
\hline & Reverse & GGG TAC ATC AAA GCC CCG AT & \\
\hline \multirow{2}{*}{ TIMP1 } & Forward & ACT TCC ACA GGT CCC ACA AC & \multirow{2}{*}{184} \\
\hline & Reverse & AAA CAG GGA AAC GTG CAT & \\
\hline
\end{tabular}

GAPDH, glyceraldehyde 3-phosphate dehydrogenase; MMP1, matrix metalloproteinase -1; TIMP1, tissue inhibitor of metalloproteinases 1. 
Equal quantities of proteins were mixed with $5 \mathrm{X}$ sample buffer (TLP-102-01, TransLab, Korea) and denatured at $99^{\circ} \mathrm{C}$ for 10 minutes. The proteins were separated by $10 \%$ SDS-PAGE at 150 V for $150 \mathrm{~min}$ and transferred to PVDF membranes (Clear Blot Membrane, 3322546, ATTO Corporation, Japan). The membranes were blocked with $0.5 \%$ bovine serum albumin (BSA, A450310G; Sigma) for 1 hour and washed with Tris-buffered saline that included Tween-20 (10X TBS with Tween 30, TR2007100-74; Biosesang, Korea) three times; membranes were then incubated with primary antibodies against MMP-1 (Recombinant Anti-MMP1 antibody [EP1249Y], ab134184, Abcam, USA), $\beta$-Actin (Anti- $\beta$-Actin (N-tern) and PA0207 (Abfrontier, Korea) at $4^{\circ} \mathrm{C}$ overnight. After rinsing, the membranes were treated with anti-rabbit IgG-horseradish peroxidase (HRP) (Anti-rabbit IgG, HRP-linked Antibody, \#7074; Cell Signaling Technology, USA) as the secondary antibody for 1 hour. Chemiluminescence detection was performed using the ECL Prime western blotting detection reagent (GE Healthcare, USA) and the ATTO WSE6100 LuminoGraph (ATTO Corporation, Japan). For quantitative analysis, the captured images were analyzed with Image software (C.S. analyzer 4, ATTO corporation, Japan).

\section{7) Statistical analysis}

Statistical analysis was performed using GraphPad Prism version 3.03 for Windows (GraphPad Software, USA). Results are presented as the mean $\pm \mathrm{SD}$ of 3 experiments. An unpaired Student's t-test was used, and p values $\langle 0.05$ were considered statistically significant.

\section{In vivo efficacy evaluation}

\section{1) Reagents and cosmetic products}

The test products were skin lotion, essence cream, and eye cream; those creams contained $1 \%$ of the MHE as the active ingredient shown in Table 3.

\section{2) Human participants}

All volunteers agreed to the purpose and content of the test and signed written informed consent forms before starting the test. They were not allowed to use any other skincare products, and the test products were applied to the face in the order of skin-eye cream (only on the crow's feet)-essence cream-lotioncream. The study was conducted according to the guidelines of the Declaration of Helsinki and approved by the Institutional Review Board of Korea National Institute for Bioethics Policy (\#P01-202108-13-001).

\section{3) Efficacy test}

Twenty-one female subjects aged between 45 and 55 (mean \pm S.D. 50.81 \pm 2.86 ) years with normal skin participated in this study. Test products were applied twice daily (morning and evening) for 4 weeks. The participants visited the research center every 2 weeks, and the test sites were measured in the laboratory, where the ambient temperature and relative humidity were maintained at $22 \pm 2{ }^{\circ} \mathrm{C}$ and $50 \pm 5 \%$, respectively. The participants acclimated for $20 \mathrm{~min}$ in the laboratory after washing their faces and were assessed for skin hydration, elasticity, texture, and crow's feet. Skin hydration was measured using a Corneometer ${ }^{\circledR}$ CM825 (C+K electronic GmbH, Cologne, Germany); elasticity was measured using a Cutometer ${ }^{\mathbb{B}}$ MPA 580 (C+K electronic GmbH, Cologne, Germany), and the texture and crow's feet were measured using a DermaTOP 3D-HE (EOTECH SAS, French).

\section{4) Evaluation of adverse reactions of the skin}

Adverse reactions were checked every visit by questionnaire and observation. In the evaluation, the subjective parameters were classified as itching, prickling, tickling, burning, stinging, stiffness, and tightening, and the objective parameters were classified as erythema, edema, scale, and papule.

\section{5) Statistical analysis}

Data were analyzed using the SPSS $^{\circledR}$ software. The statistical

Table 3. Composition of active ingredients of test products used in this study

\begin{tabular}{lll}
\hline No. & Classification & Content of active ingredient \\
1 & Skin & Mixed herbal extract (MHE) $1 \%$ \\
3 & Lotion & \\
4 & Essence cream & Eye cream \\
\hline
\end{tabular}




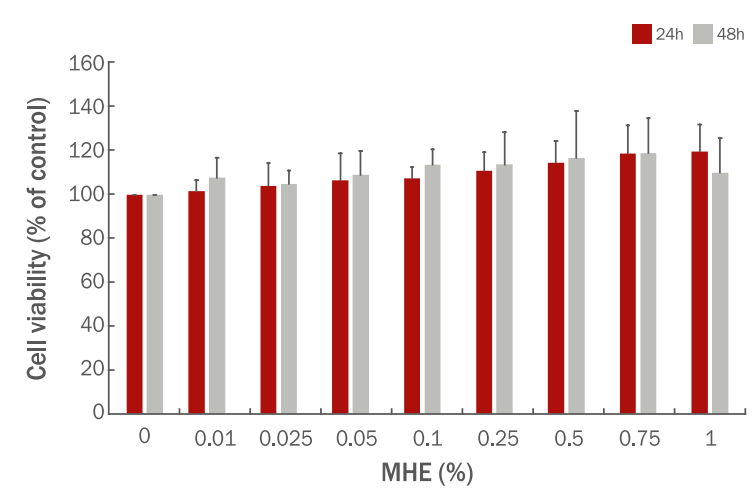

Figure 1. Effects of MHE on normal human dermal fibroblast cell viability.

MHE did not significantly reduce the viability of human fibroblast cells. Data are shown as mean \pm S.D. of three experiments. ${ }^{*} p<0.05$ compared to control. MHE, mixed herbal extract.

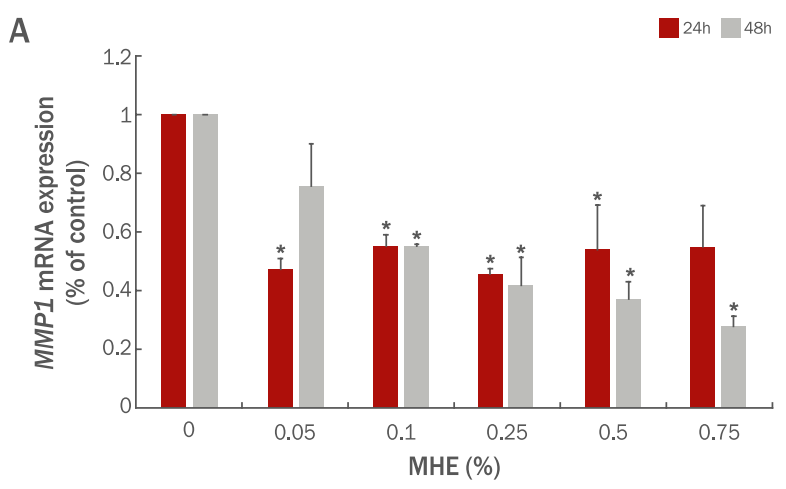

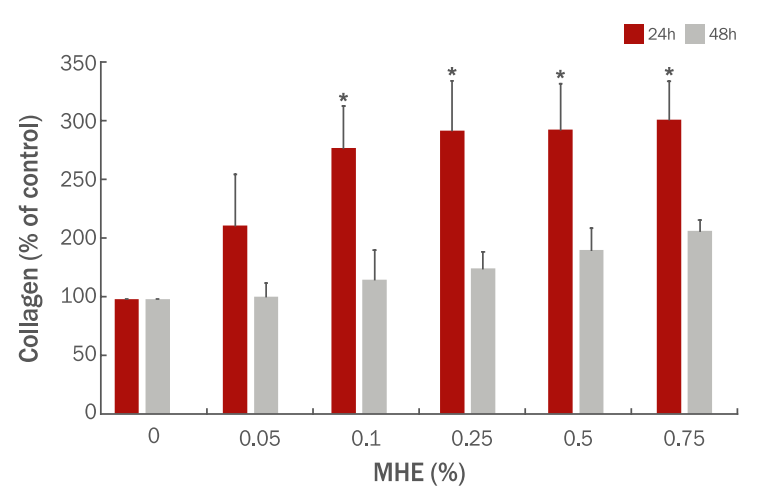

Figure 2. Effects of MHE on pro-collagen type I expression in normal human dermal fibroblast.

MHE can strongly increases pro-collagen type I content. Data are shown as mean \pm S.D. of three experiments. ${ }^{*} p<0.05$ compared to control. MHE, mixed herbal extract.

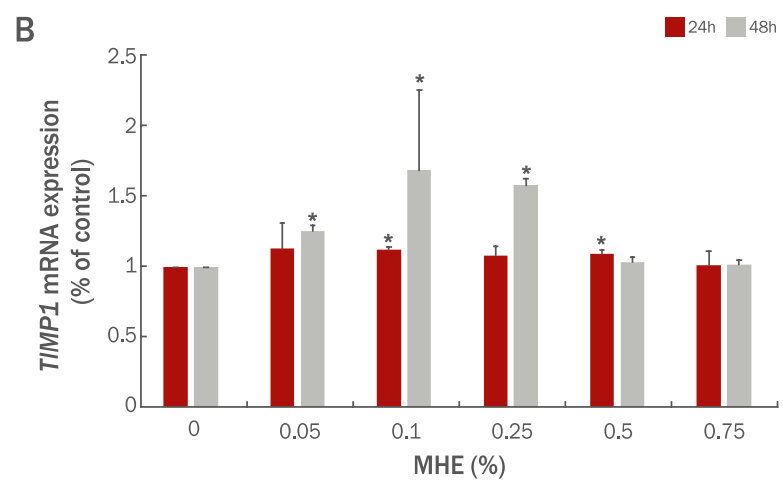

Figure 3. Effects of MHE on MMP1 and TIMP1 mRNA expression in normal human dermal fibroblast.

MMP1 (A) and TIMP1(B) were quantified by real time PCR. The data are shown as mean \pm S.D. of three experiments. ${ }^{*} p<0.05$ compared to control. MMP1, matrix metalloproteinase-1; TIMP1, tissue inhibitor of metalloproteinases 1.

significance of the differences between time points was determined using repeated measures analysis; a $p$-value $\langle 0.05$ was considered statistically significant. The change rate (\%) from the baseline value was calculated as follows:

Change rate $=(($ after treatment-baseline $) /$ baseline $) \times 100 \%$

\section{Results}

\section{Anti-aging effect of the MHE in vitro \\ 1) Effects of the MHE on cell viability}

To measure the cell viability of the MHE on normal human dermal fibroblasts, the cells were treated with various concentrations $(0.01 \%, 0.025 \%, 0.05 \% .0 .10 \%, 0.25 \%, 0.50 \%$,
$0.75 \%$, and $1.00 \%$ ) of the MHE. The results suggest that MHE did not significantly reduce the viability of human fibroblast cells (Figure 1) and was safe to use at all the concentrations.

2) Effects of the MHE on pro-collagen expression

The effects of the MHE on pro-collagen type I expression were studied in cultured normal human dermal fibroblasts. Compared with normal cells, the MHE treatment with concentrations of $0.05 \%, 0.10 \%, 0.25 \%, 0.50 \%$, and $0.75 \%$ can strongly increase the procollagen type I content. The effect of the MHE on pro-collagen type I expression was found to be dose dependent (Figure 2).

3) Effects of the MHE on MMP1 and TMP1 gene expressions The gene expressions of MMP1 and TIMP1 were examined 
A

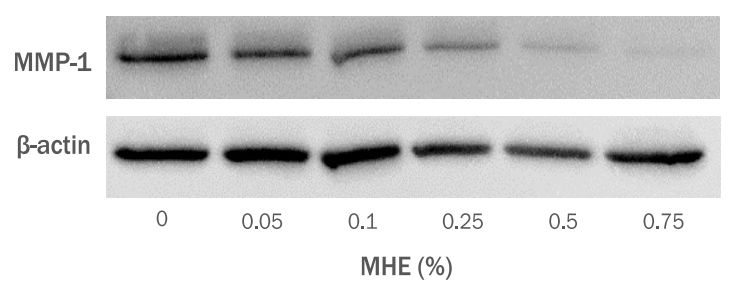

B

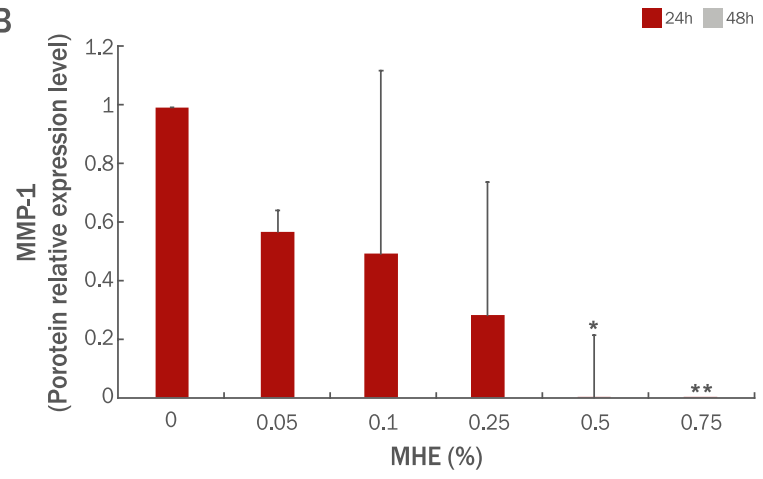

Figure 4. Effects of MHE on MMP1 protein expression in HDFn.

(A) MMP-1 was analyzed by Western Blotting using specific antibodies against MMP1. b-actin served as loading control in HDFn cells. (B) Three independent Western Blots were quantified by densitometry using Image Lab Software. The protein expression of MMP1 was normalized with respect to the corresponding b-actin signals of the appropriate samples. The data are shown as the mean \pm S.D. of three experiments. ${ }^{*} p<0.05 ;{ }^{* *} p<0.01$ compared to control. MMP1, matrix metalloproteinase-1; MHE, mixed herbal extract; HDFn, human primary fibroblast cells.

Table 4. Statistical data of skin hydration, elasticity, and texture

\begin{tabular}{|c|c|c|c|c|}
\hline Classification & Time point & Mean $\pm S D$ & $p$-value ${ }^{3}$ & Change from baseline (\%) \\
\hline \multirow{3}{*}{ Skin hydration (A.U.) $)^{1}$} & Baseline & $46.85 \pm 9.12$ & - & - \\
\hline & 2 weeks & $58.37 \pm 8.11$ & $0.000^{*}$ & $24.60 \Delta$ \\
\hline & 4 weeks & $62.33 \pm 8.79$ & $0.000^{*}$ & $33.04 \Delta$ \\
\hline \multirow{3}{*}{ Skin elasticity $(\mathrm{mm})^{1}$} & Baseline & $0.633 \pm 0.061$ & - & - \\
\hline & 2 weeks & $0.693 \pm 0.049$ & $0.000^{*}$ & $9.51 \Delta$ \\
\hline & 4 weeks & $0.705 \pm 0.062$ & $0.000^{*}$ & $11.40 \boldsymbol{\Delta}$ \\
\hline \multirow{3}{*}{ Skin texture $(S a, \mu m)^{2}$} & Baseline & $12.76 \pm 3.48$ & - & - \\
\hline & 2 weeks & $13.00 \pm 2.65$ & 0.692 & $1.87 \triangle$ \\
\hline & 4 weeks & $11.43 \pm 1.96$ & $0.008^{*}$ & $10.45 \boldsymbol{\nabla}$ \\
\hline \multirow{3}{*}{ Skin texture $(\mathrm{Stm}, \mu \mathrm{m})^{2}$} & Baseline & $130.48 \pm 41.24$ & - & - \\
\hline & 2 weeks & $130.86 \pm 29.99$ & 0.957 & $0.29 \triangle$ \\
\hline & 4 weeks & $115.33 \pm 19.98$ & $0.012^{*}$ & $11.61 \nabla$ \\
\hline
\end{tabular}

${ }^{1}$ Increment of mean value represents improvement of skin hydration, elasticity $(\mathbf{\Lambda})$.

${ }^{2}$ Decrement of mean value represents improvement of skin texture $(\boldsymbol{\nabla})$.

${ }^{3}$ Significantly different at ${ }^{*} p<0.05$ vs. baseline.

by real time PCR. MHE significantly downregulated the MMP1 mRNA level in a dose-dependent manner at 48 hours (Figure 3A). Additionally, MHE downregulated MMP1 gene expression level to half at concentrations of $0.05 \%$ and $0.25 \%$ at 24 hours. In contrast, TIMP1 was increased in the cells treated with MHE at concentrations of $0.05 \%, 0.1 \%$, and $0.25 \%$ (Figure 3B), which was probably related to the decrease in $M M P 1$ expression. Thus, MHE downregulated MMP1 and upregulated TIMP1 and hence has a good anti-aging effect.

\section{4) Effects of the MHE on MMP1 protein expression}

To investigate whether MHE attenuates skin aging, HDFn cells were treated with different concentrations of the MHE, and the protein expression of MMP1 was detected by Western Blotting. The results indicate that the MHE treatment significantly decreased the expression level of MMP1 (Figure 4A, 4B) in a dosedependent manner.

\section{Skin improvement effect of the MHE in vivo}

In comparison to the baseline, skin hydration significantly increased at 2 and 4 weeks after the treatment. The increments were $24.60 \%$ and 33.04\%, respectively (Table 4 and Figure 5A). Skin elasticity significantly increased at 2 and 4 weeks after the treatment. The increments were $9.51 \%$ and $11.40 \%$, respectively 
A

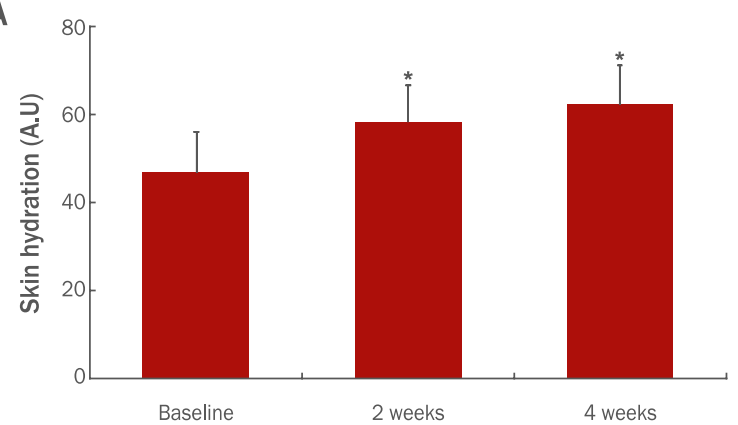

C

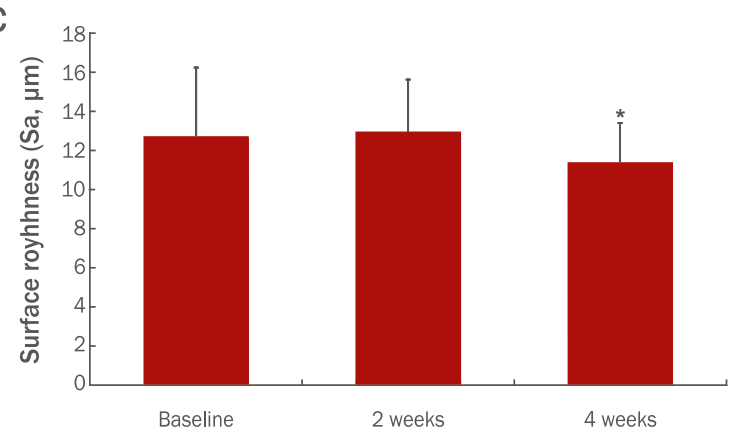

E

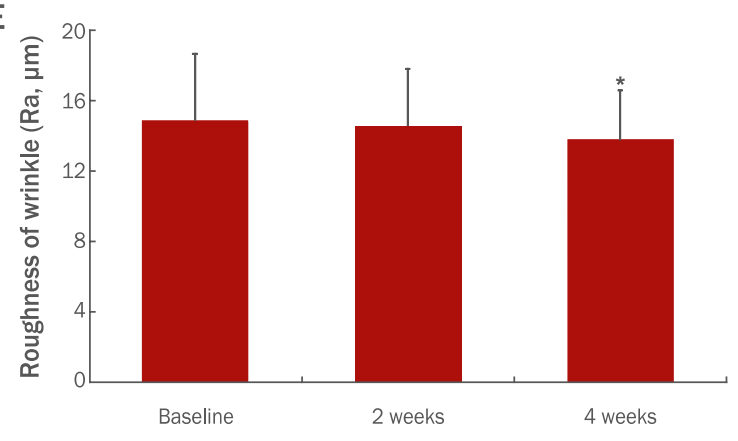

G

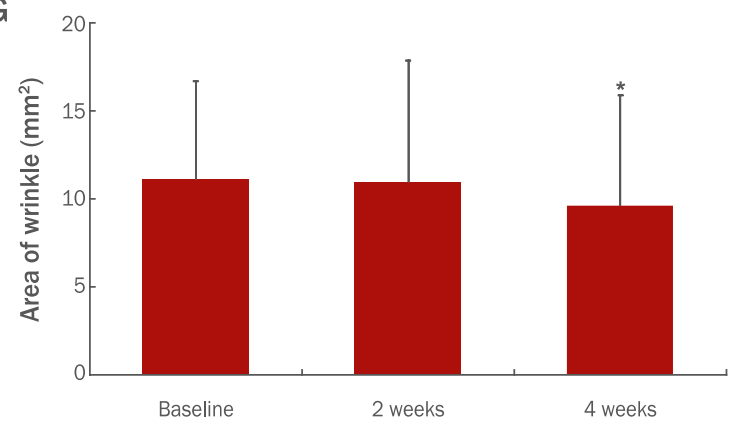

B

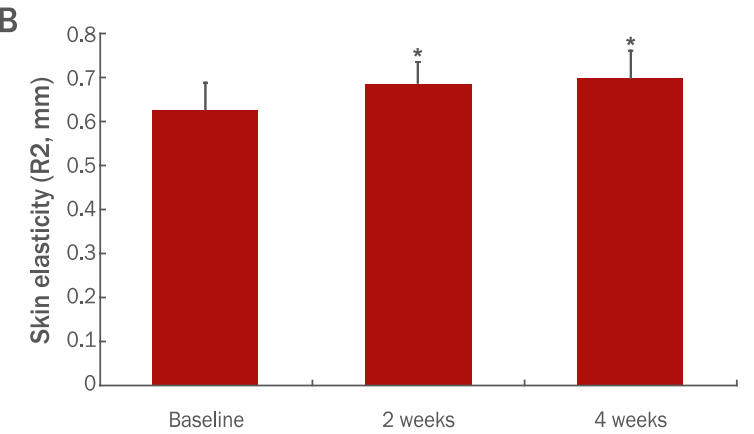

D

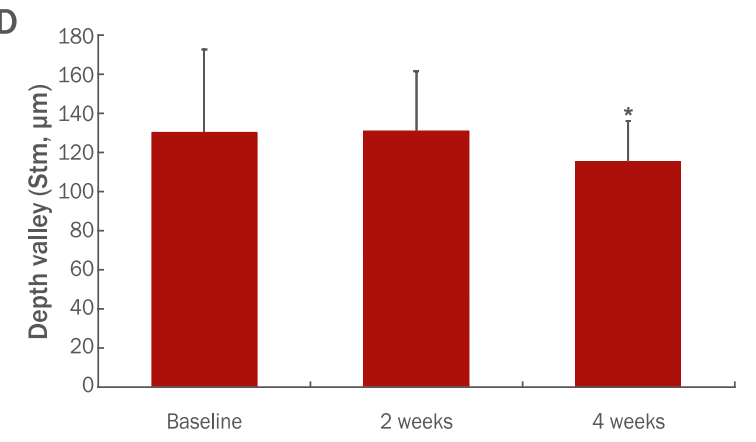

$\mathbf{F}$

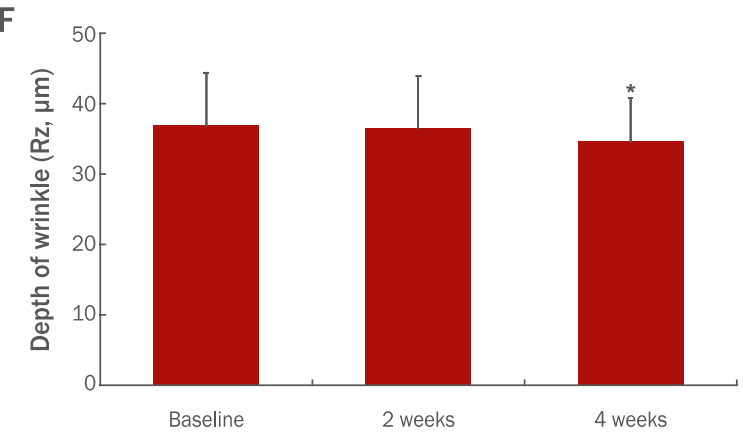

H

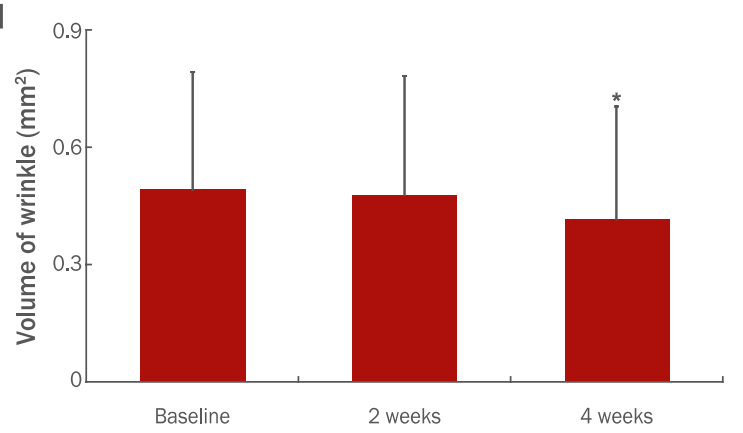

Figure 5. Changes of skin condition after application of test products for $\mathbf{4}$ consecutive weeks.

(A) Skin hydration value, (B) Skin elasticity value (R2 parameter), (C, D) Skin texture parameters, (E, F, G, H) Crow's feet parameters. Data were presented as means+standard deviation of means. $(n=21) .{ }^{*} p<0.05$ vs. baseline. 
(Table 4 and Figure 5B). In the case of skin texture, all parameters (Sa and Stm) were significantly improved at four weeks after the treatment. The improvement rate of the Sa parameter was $10.45 \%$ and that of the Stm parameter was $11.61 \%$ (Table 4 and 6 and Figure 5C, 5D). In the case of the crow's feet, all parameters (Ra, Rz, area and volume) were significantly improved at 4 weeks after the treatment. The improvement rates of the Ra, Rz, Area and Volume parameters were $7.35 \%, 6.18 \%, 13.41 \%$ and $15.29 \%$, respectively, (Table 5 and 6, and Figure 5E, 5F, 5G, 5H). No adverse reactions were observed in any of the participants during the test period. No itching, prickling, tickling, burning, stinging, stiffness, or tightening were experienced by the participants. In addition, no erythema, edema, scale, or papule were observed by the examiners.

\section{Discussion}

Skin aging is a complex biological process that is affected by a combination of endogenous and exogenous factors. The endogenous factors are genetics, cellular metabolism, hormones, and metabolic processes. The exogenous factors are chronic light exposure, contamination, ionizing radiation, chemicals, and toxins. Various aging factors combine leading to accumulated structural and physiological changes and gradual changes in each skin layer and to changes in the appearance of the skin, especially in areas where the skin was exposed to the sun (Cevenini et al., 2008; Ganceviciene et al., 2012). The skin is an organ that shows the most marks from aging. Therefore, many researchers are making efforts to develop new skin anti-aging

Table 5. Statistical data of skin wrinkles

\begin{tabular}{|c|c|c|c|c|}
\hline Parameter & Time point & $\operatorname{Mean}^{1} \pm \mathrm{SD}$ & $p$-value ${ }^{2}$ & Change from baseline (\%) \\
\hline \multirow{3}{*}{$\mathrm{Ra}(\mu \mathrm{m})$} & Baseline & $14.90 \pm 3.73$ & - & - \\
\hline & 2 weeks & $14.52 \pm 3.27$ & $0.730^{\mathrm{w}}$ & $2.56 \nabla$ \\
\hline & 4 weeks & $13.81 \pm 2.75$ & $0.008^{*_{\mathrm{w}}}$ & $7.35 \boldsymbol{\nabla}$ \\
\hline \multirow{3}{*}{$\mathrm{Rz}(\mu \mathrm{m})$} & Baseline & $37.00 \pm 7.54$ & - & - \\
\hline & 2 weeks & $36.62 \pm 7.40$ & $0.810^{w}$ & $1.03 \boldsymbol{\nabla}$ \\
\hline & 4 weeks & $34.71 \pm 6.28$ & $0.012^{* \mathrm{w}}$ & $6.18 \nabla$ \\
\hline \multirow{3}{*}{ Area $\left(\mathrm{mm}^{2}\right)$} & Baseline & $11.10 \pm 5.51$ & - & - \\
\hline & 2 weeks & $10.938 \pm 6.8$ & 0.868 & $1.53 \boldsymbol{\nabla}$ \\
\hline & 4 weeks & $9.61 \pm 6.24$ & $0.028^{*}$ & $13.41 \nabla$ \\
\hline \multirow{3}{*}{ Volume $\left(\mathrm{mm}^{2}\right)$} & Baseline & $0.49 \pm 0.30$ & - & - \\
\hline & 2 weeks & $0.48 \pm 0.31$ & 0.795 & $2.70 \nabla$ \\
\hline & 4 weeks & $0.42 \pm 0.29$ & $0.047^{*}$ & $15.29 \nabla$ \\
\hline
\end{tabular}

${ }^{1}$ Decrement of mean value represents improvement of skin wrinkles $(\boldsymbol{\nabla})$.

${ }^{2}$ Significantly different at ${ }^{*} p<0.05$ vs. baseline.

${ }^{\mathrm{w}}$ Wilcoxon signed ranks test.

Table 6. Images of skin texture and wrinkles of subjects

\begin{tabular}{|c|c|c|c|c|}
\hline \multirow{2}{*}{ Classification } & \multicolumn{2}{|c|}{ Skin texture (Subject No. 04) } & \multicolumn{2}{|c|}{ Skin wrinkle (Subject No. 23) } \\
\hline & Baseline & 4 weeks & Baseline & 4 weeks \\
\hline \multicolumn{5}{|l|}{ Digital image } \\
\hline \multicolumn{5}{|l|}{ 3D image } \\
\hline Topo-graphy image ${ }^{*}$ & & & & \\
\hline
\end{tabular}

"Topography image: analyzed image acquired by detecting depression of skin surface. 
materials. Traditional herbal medicines provide an interesting, largely unexplored source for the development of potential new drugs. The potential use of traditional herbal medicines for the development of new skin-care cosmetics has been emphasized recently (Kiken \& Chhen, 2012).

The purpose of this study was to develop a cosmetic ingredient with anti-aging and anti-wrinkle functions based on herbal medicines. For this, six medicinal herbs were mixed and extracted based on the "Yin-Yang" and "Five Elements" theory. To test the anti-aging effect of the MHE, we evaluated skin collagen production, MMP1 inhibition, and TIMP1 promoting effects. To elucidate whether the MHE results in wrinkle improvement, the inhibitory activities of MMP1 and the promoting activities of collagen type I synthesis and TIMP1 were measured using HDFn cells. As a result of the test, it was revealed that the MHE has the effect of improving skin wrinkles by increasing the amount of collagen production in the HDFn cells and inhibiting the gene expression and protein production of MMP1. In addition, there is an effect of promoting the gene expression of TIMP1, which inhibits MMP1. It was further confirmed that hydration, elasticity, texture, and wrinkles all improved within 4 weeks compared to before use on the skin of the lotion, essence, eye cream, and cream applied with $1 \% \mathrm{MHE}$ Therefore, it was confirmed that the MHE has an anti-aging effect by improving skin wrinkles.

In this study, ultrasonic extraction used for the medicinal herbal extraction is an extraction method widely used in plant extraction along with Soxhlet extraction, immersion extraction, pressure extraction, reflux extraction, and accelerated solvent extraction. The ultrasonic extraction method has the advantage of low solvent usage and easy extraction; thus, it is a popular extraction method when considering aspects such as economic efficiency and time of the extraction process (Wan et al., 2006). There are various methods for extracting plant components, and different types of solvents may be used such as water and ethanol, or different extraction methods may be used including pressure extraction and reflux extraction such as ultrasonic extraction. In addition, the extraction conditions can be changed such as the extraction time, temperature, and $\mathrm{pH}$. It is important to find the optimal extraction method for each plant because the type and degree of physiological activity of a plant extract may vary depending on the extraction method. In this study, six medicinal herbs were extracted using ultrasonic extraction; however, when other extraction methods are used, whether the physiologically active ingredients and skin effects change compared to the MHE used in this study should be clarified by further study.

The six herbal medicines have various medical and skin effects including an anti-aging effect. Therefore, it is predictable that by using them, the MHE has an anti-aging effect. Additionally, the MHE has the potential to be effective in skin-related whitening, as an antioxidant and anti-inflammatory agent and in atopy improvement. Among the components of the $\mathrm{MHE}$, the Forsythiae fructus extract has been reported to have a whitening effect, and the antioxidant functions of Siberian ginseng, Solomon's seal, Ponciri fuctus and ginseng have been reported. Each extract contains various flavonoids, which also have antioxidant properties (Choi, 2008; Dong et al., 2017; Fathi et al., 2014; Huang et al., 2011; Kong \& Kwon, 2021; Yang $\&$ Choe, 2011). Antioxidants inhibit tyrosinase and interfere with melanin biosynthesis, which can have a skin whitening effect (Briganti et al., 2003; Solano et al., 2006). Therefore, it is possible that MHE, which is supposed to contain flavonoids or other antioxidants, may have a skin whitening effect. In addition, the MHE, which contains herbs with anti-inflammatory and atopy-improving effects (Bao et al., 2016; Dong et al., 2017), has the potential to improve atopic dermatitis and to have antiinflammatory and wound healing effects. All these possibilities should be confirmed by further study.

In this study, the anti-aging effect of the MHE extracted from six medicinal herbs with various medical and skin effects was confirmed, and the skin improvement effect was confirmed on the facial skin by applying it to cosmetics. We developed a new cosmetic ingredient, MHE, and confirmed its value as a skin anti-aging ingredient. Therefore, it is expected that cosmetics that include the MHE can significantly contribute to the improvement of skin aging.

\section{Conclusion}

In this study, MHE containing Forsythiae fructus, Tribuli fructus, Solomon's seal, Siberian ginseng, Ponciri fructus, and Ginseng showed an anti-wrinkle activity in dermal fibroblast cells. In addition, the moisturizing, elasticity-improving, and skin texture activities of the MHE were elucidated by clinical tests. It seems that the MHE can be used as a skin anti-aging ingredient in functional cosmetics. 


\section{Author's contribution}

MLSY designed this investigation, performed experiment, and wrote the manuscript with assistance from AHY. AHY, KWS performed experiments and data analysis. HJC performed the preparation of the MHE samples. LXX and JHH performed the preparation of the cosmetics. PHW, CJH oversaw the project.

\section{Author details}

Soyoun Lee (Senior Researcher), Skin Science Research Center, New Life Cosmetics R\&D Center, New Life Group Corporation, Seoul 08594, Korea; Hongyan An (Associate Researcher), Skin Science Research Center, New Life Cosmetics R\&D Center, New Life Group Corporation, Seoul 08594, Korea; Woosoo Kim (Assistant Researcher), Skin Science Research Center, New Life Cosmetics R\&D Center, New Life Group Corporation, Seoul 08594, Korea; Xinxin $\mathrm{Lu}$ (Senior Researcher), New Life Cosmetics R\&D Center Co., Ltd, Shanghai 200233, China; Hyanghwa Jeon (Principal Reseacher), New Life Cosmetics R\&D Center, New Life Group Corporation, Seoul08594, Korea; Han Woong Park (Director), Skin Science Research Center, New Life Cosmetics R\&D Center, New Life Group Corporation, Seoul 08594, Korea; Jeongcheol Ha (Managing Director), New Life Cosmetics R\&D Center Co., Ltd, Shanghai 200233, China; Jinhun Cho (Vice President), New Life Cosmetics R\&D Center Co., Ltd, Shanghai 200233, China.

\section{References}

Bao J, Ding R, Zou L, Zhang C, Wang K, Liu F, Li P, Chen M, Wan $\mathrm{JB}, \mathrm{Su} \mathrm{H}$, et al. Forsythiae Fructus inhibits B16 melanoma growth involving MAPKs/Nrf2/HO-1 mediated antioxidation and Anti-Inflammation. The American Journal of Chinese medicine, 44: 1043-1061, 2016.

Binic I, Lazarevic V, Ljubenovic M, Mojsa J, Sokolovic D. Skin ageing: natural weapons and strategies. Evidence-Based Complementary and Alternative Medicine, 2013: 827248, 2013.

Briganti S, Camera E, Picardo M. Chemical and instrumental approaches to treat hyperpigmentation. Pigment Cell Research, 16: 101-110, 2003.

Cevenini E, Invidia L, Lescai F, Salvioli S, Tieri P, Castellani
G, Franceschi C. Human models of aging and longevity. Expert Opinion on Biological Therapy, 8: 1393-1405, 2008.

Chhatre S, Nesari T, Somani G, Kanchan D, Sathaye S. Phytopharmacological overview of Tribulus terrestris. Pharmacognnogy Reviews, 8: 45-51, 2014.

Choi HR, Nam KM, Lee HS, Yang SH, Kim YS, Lee J, Date A, Toyama K, Park KC. Phlorizin, an active ingredient of Eleutherococcus senticosus, increases proliferative potential of keratinocytes with inhibition of MiR135b and increased expression of type IV collagen. Oxidative Medicine and Cellular Longevity, 2016: 3859721, 2016.

Choi KT. Botanical characteristics, pharmacological effects and medicinal components of Korean Panax ginseng $\mathrm{C}$ A Meyer. Acta Pharmacologica Sinica, 29: 1109-1118, 2008.

Dong Z, Lu X, Tong X, Dong Y, Tang L, Liu M. Forsythiae fructus: a review on its phytochemistry, quality control, pharmacology and pharmacokinetics. Molecules, 22: 1466, 2017.

Farage MA, Miller KW, Elsner P, Maibach HI. Characteristics of the aging skin. Advanced in Wound Care, 2: 5-10, 2013.

Fathi FM, Harita H, Mahmood AA, Suzy SM, Salmah I, Zahra AA, Kamal K. Acceleration of wound healing activity by Polygonatum odoratum leaf extract in rats. Journal of Medicinal Plants Research, 8: 523-528, 2014.

Ganceviciene R, Liakou Al, Theodoridis A, Makrantonaki E, Zouboulis CC. Skin anti-aging strategies. Dermatoendocrinology, 4: 308-319, 2012.

Haroon K, Muhammad S, Naveed M. Pharmacological and phytochemical updates of genus Polygonatum. Phytopharmacology, 3: 286-308, 2012.

He N, Zhao S, He Y, Xu M, Meng H, Yi F. Current status of research on ginseng cosmetics. Asian Journal of Beauty and Cosmetology, 16: 609-616, 2018.

Huang L, Zhao H, Huang B, Zheng C, Peng W, Qin L. Acanthopanax senticosus: review of botany, chemistry and pharmacology. Pharmazie, 66: 83-97, 2011

Hwang GH, Lee EJ, Song BK, Kim HK. Mechanism of inhibitory action of anaphylaxis by aqueous extract of Poncirus trifoliata. Journal of Korean Oriental Medicine, 18: 316325, 1997.

Jung SA, Choi YY, Yang WM. Anti-atopic dermatitis effects of Rafinesque via regulation of immune response and nerve 
growth factor. Journal of Korean Medicine, 37: 10-20, 2016. DOI: $10.13048 / \mathrm{jkm} .16002$

Kiken DA, Cohen DE. Contact dermatitis to botanical extracts. American Journal of Contact Dermatitis, 13: 148-152, 2002.

Kim HS, Ko KS, Antioxidant and anti-inflammatory effects of ginseng berry ethanol extracts as a cosmetic ingredient. Asian Journal of Beauty and Cosmetology, 18: 389-397, 2020.

Kim MJ, Jung TK, Park HC, Yoon KS. Skin volume augmentation and anti-wrinkle effects of tribulus terrestris fruit extract. Korean Society for Biotechnology and Bioengineering Journal, 31: 178-185, 2016.

Kim YS, Cho IH, Jeong MJ, Jeong SJ, Nah SY, Cho YS, Kim SH, Go A, Kim SE, Kang SS, Moon CJ, Kim JC, Kim SH, Bae CS. Therapeutic effect of total ginseng saponin on skin wound healing. Journal of Ginseng Research, 35: 360367, 2011.

Kong GB, Kwon OH. Antioxidant effects of Ponciri fructus bioconversion extracts as cosmetic ingredients. Asian Journal of Beauty and Cosmetology, 19: 477-485, 2021.

Landau M. Exogenous factors in skin aging. Current Problems in Dermatology, 35: 1-13, 2007.

Lee AY, Chun JM, Jang S, Choo BK, Lee HW, Kim HK. Change of quality in Poncirus trifoliata Rafinesque according to storage conditions. Korean Journal of Medicinal Crop Science, 16: 188-191, 2008.

Lovell CR, Smolenski KA, Duance VC, Light ND, Young S, Dyson M. Type I and III collagen content and fibre distribution in normal human skin during ageing. British Journal of Dermatology, 117: 419-428, 1987.

Makrantonaki E, Zouboulis CC. William J. cunliffe scientific awards. Characteristics and pathomechanisms of endogenously aged skin. Dermatology, 214: 352-360, 2007.

Mays PK, Bishop JE, Laurent GJ. Age-related changes in the proportion of types I and III collagen. Mechanisms of Ageing and Development, 45: 203-212, 1988.

Park KJ, Park SH, Kim JK. Anti-wrinkle activity of Acanthopanax senticosus extract in ultraviolet B (UVB)-induced photoaging. Journal of the Korean Society of Food Science and Nutrition, 39: 42-46, 2010.

Slominski A, Tobin DJ, Shibahara S, Wortsman J. Melanin pigmentation in mammalian skin and its hormonal regulation. Physiological Reviews, 84: 1155-1228, 2004.

Solano F, Briganti S, Picardo M, Ghanem G. Hypopigmenting agents: an updated review on biological, chemical and clinical aspects. Pigment Cell Research, 19: 550-571, 2006.

Vollmer DL, West VA, Lephart ED. Enhancing skin health: by oral administration of natural compounds and minerals with implications to the dermal microbiome. International Journal of Molecular Sciences, 19, 2018.

Wan JB, Lai CM, Li SP, Lee MY, Kong LY, Wang YT. Simultaneous determination of nine saponins from Panax notoginseng using HPLC and pressurized liquid extraction. Journal of Pharmaceutical and Biomedical Analysis, 41: 274-9, 2006.

Wang Z, Xia Q, Liu X, Liu W, Huang W, Mei X, Luo J, Shan M, Lin R, Zou D, et al. Phytochemistry, pharmacology, quality control and future research of Forsythia suspensa (Thunb.) Vahl: a review. Journal of Ethnopharmacology, 210: 318339, 2018.

Wlaschek M, Tantcheva-Poór I, Naderi L, Ma W, Schneider LA, Razi-Wolf Z, Schüller J, Scharffetter-Kochanek K. Solar UV irradiation and dermal photoaging. Journal of Photochemistry and Photobiology B: Biology, 63: 41-51, 2001.

Yang SJ, Choe TB. Antioxidant activity and whitening effect of Forsythiae fructus extracts. Korean Journal of Medicinal Crop Science, 19: 472-477, 2011. 


\section{국문초록}

\section{복합 약용 식물 추출물의 항노화 효과}

이소연 ${ }^{1}$, 안홍연 $^{1}$, 김우수 ${ }^{1}$, 루신신 ${ }^{3}$, 전향화 ${ }^{2}$, 박한웅 $^{1}$, 하정철 ${ }^{3}$, 조진훈 ${ }^{*}$

${ }^{1}$ 뉴라이프그룹 신생활화장품연구소 피부과학연구소, 서울, 한국

${ }^{2}$ 뉴라이프그룹 신생활화장품연구소, 서울, 한국

${ }^{3}$ 신생활화장품연구소, 상하이, 중국

목적: 본 연구는 음양오행의 원리를 기반으로 개발한 복합 약용 식물 추출물(mixed herbal extract, MHE) 피부 세포에서 항노화 효 능을 가지고 있는지를 확인하고 실제 화장품에 적용하여 in vivo 평가를 수행함으로써 피부 항노화 화장품 성분으로서 이용 가치를 확인하기 위해 진행되었다. 방법: 본 연구에서는 피부 노화 방지 효과가 있는 성분 개발을 위하여 연교, 질려자, 가시오가피, 옥죽, 지실 및 인삼을 포함하는 초음파 추출을 사용하여 $\mathrm{MHE}$ 을 제조하였다. 이 복합 추출물을 이용해 섬유아세포에서 콜라겐 생성량 및 콜라겐 합성 및 분해와 관련된 MMP1과 TIMP1의 발현에 미치는 효과를 확인하였다. 또한 $1 \% \mathrm{MHE}$ 를 함유한 화장품을 사용하여 피부 수분, 탄력, 결, 주름에 대한 임상 시험을 수행하였다. 결과: MHE는 pro-collagen type I 합성과 TIMP1 mRNA 발현을 촉진 할 뿐 아니라 MMP1 mRNA 및 단백질의 발현을 억제하는 효과를 가짐을 확인하였다. 또한, $1 \% \mathrm{MHE}$ 를 함유 한 화장품을 피부에 도포한 결과, 4 주 후 피부 보습, 탄력, 결, 눈가가 개선되었다. 결론: MHE가 피부 세포에서 콜라겐 합성을 촉진하고 MMP1유전자 발현을 억제하는 효과를 가지고 있음을 확인하였으며, $\mathrm{MHE}$ 를 적용한 화장품의 임상 시험에서 피부 개선 효과 확인하였다. 이를 통 해 MHE가 피부 항노화 화장품 성분으로서 가치가 있음을 확인하였다.

핵심어: 스킨케어, 항노화, 주름 개선, 천연화장품, 한약재

\section{참고문헌}

공규빈, 권오혁. 지실 생물전환 추출물의 항산화 효과. 아시안뷰티화장품학술지, 19: 477-485, 2021.

김미진, 정택규, 박현철, 윤경섭. 질려자 추출물의 피부 볼륨 증진 및 주름개선 효과. 한국생물공학회지, $31: 178-185$, 2016

김현숙, 고경숙. 인삼열매 에탄올 추출물의 화장품 소재로서 항산화, 항염 효과. 아시안뷰티화장품학술지, 18: 389-397, 2020

박금주, 박승희, 김재기. 가시오가피 추출물의 광노화에 의한 주름형성 억제 효과. 한국식품영양과학회지, $39,1,42-46$, 2010

이아영, 천진민, 장설, 추병길, 이혜원, 김호경. 보관조건에 따른 유통생약 지실의 품질변화 연구. 한국약용작물학회지, 16: $188-191,2008$.

정선아, 최유연, 양웅모. 면역반응 및 신경성장인자 조절을 통한 지실의 항아토피 효능. 대한한의학회지, 27: 10-20, 2016

황광호, 리은정, 송봉근, 김현경. 郎時型 알레르기 反應에 있어서 물抽出液의 抑制作用機轉. 대한한의학회지, 18: $316-$ 325, 1997

허남, 조시기, 하일범, 허명량, 맹홍, 역범. 인삼 화장품 연구 현황. 아시안뷰티화장품학술지, 16: 609-616, 2018. 


\section{中文摘要}

\section{中草药混合提取物的抗衰老作用}

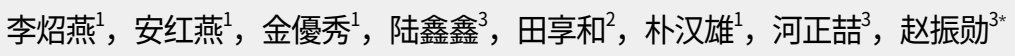

${ }^{1}$ New Life Cosmetics 新生活化妆品研究所皮肤科学研究所, 首尔, 韩国

${ }^{2}$ New Life Cosmetics 新生活化妆品研究所, 首尔, 韩国

3新生活化妆品研究所, 上海, 中国

目的: 通过研究混合草药提取物 (MHE) 在体外和体内的皮肤抗衰老活性, 确认其作为抗衰老化妆品成分的适用 性。方法: 在本研究中, 使用含有连翘、晸葱、所罗门海豹、西伯利亚人参、枳椇和人参的超声波提取法制备 $M H E 。 M H E$ 对真皮成纤维细胞中皮肤的抗衰老作用。抗衰老活性由 I 型胶原蛋白合成水平决定。通过 qRT-PCR 测量基质金属蛋白酶 1 (MMP1) 和金属蛋白酶组织抑制剂 1 (TIMP1) mRNA 水平。通过印迹分析评估 MMP1 蛋 白水平。使用含有 $1 \%$ MHE 的化妆品进行皮肤水分、弹性、质地和皱纹的临床测试。结果: MHE诱导I型前胶原 合成和TIMP1 mRNA表达的上调。MHE 导致 MMP1 mRNA 水平和蛋白质水平的下调。此外, 在皮肤涂抹含有 $1 \% \mathrm{MHE}$ 的化妆品后，皮肤的水分、弹性、质地和鱼尾纹在治疗后 4 周得到改善。结论: MHE在体外通过促进 胶原蛋白合成和抑制MMP1基因表达具有抗衰老作用，在体内具有改善皮肤的作用。因此，MHE 被证明具有作 为功能性化妆品成分的价值。

关键词: 护肤, 抗衰老, 抗皱, 天然化妆品, 草药 